УДК 378:355]:17.035.3-054

DOI: 10.37026/2520-6427-2020-104-4-125-128
ОльГа ШЕЛЮХ,

кандидат філологічних наук,

дочент кафедри гуманітарних наук

Національної академії сухопутних військ

імені гетьмана Петра Сагайдачного, м. Київ

Наталія ВОВЧАСТА,

доктор педагогічних наук, доиент,

професор кафедри фундаментальних дисииплін

ПЗВО «ІТ СТЕП Університет», м. Львів

\title{
ФОРМУВАННЯ НАЦІОНАЛЬНОЇ ІДЕНТИЧНОСТІ В КУРСАНТІВ ВІЙСЬКОВИХ ЗАКЛАДІВ ВИЩОї ОСВІТИ
}

У статті розглядається проблема розуміння понять «начіональна свідомість», «національна ідентичність», «самоідентифікація» в сучасному молодіжному середовищі, а також питання важливості їх формування у військових закладах вишої освіти. Представлені результати опитування першокурсників Національної академії сухопутних військ імені гетьмана Петра Сагайдачного шчодо розуміння таких важливих засадничих понять, як «національна свідомість» $i$ «начіональна ідентичність».

Ключові слова: начія, начіональна свідомість, національна ідентичність, когнітивний дисонанс.

Nowadays Ukraine is faced with the question of the role of its young people in the modern society. Therefore, the problem of understanding the concept of «national consciousness», "national identity», "self-identification» in the modern youth society, as well as the importance of forming these concepts in the higher military educational establishments is shown in the article.

In addition, the results of freshmen's questionnaire of the National Army Academy named after Hetman Petro Sahaidachnyi as for the understanding of such key concepts as the "national consciousness» and «national identity" are presented. The results of the questionnaire are shown. The native language playes a key role in the formation of national consciousness. It is emphasized that the language environment is a powerful vector in the formation of national identity which needs special attention.

The scientific and pedagogical staff of the higher military educational establishments is played the important role. The language environment forms the «humanitarian aura» of the future defender of state and national interests, Ukrainians with their language, history, religion, culture and their identifications.

The complex of humanitarian disciplines, organizational and educational activities, moral and psychological, spiritual content of the "humanitarian aura» are concluded in the research work. The language environment will contribute to the formation and development of national consciousness of every participant of the pedagogical process.
Key words: the higher military educational establishments, cadet, national consciousness, national identity, self-identification, scientific and pedagogical staff.

Постановка проблеми. Випускники військових закладів вищої освіти повинні бути спроможними протистояти всім цивілізаційним викликам, що зумовлені суспільно-політичними та військовими чинниками сьогодення. Тому першочерговим завданням військових закладів вищої освіти (далі - BЗВО) $\epsilon$ підготовка високоосвічених та конкурентоспроможних фахівців для Збройних Сил та інших військових формувань України.

У зв'язку з цим потрібно ретельно й комплексно підійти до змістового наповнення системи підготовки майбутнього офіцера, від діяльності якого залежить не лише територіальна, а й національна безпека держави в цілому. У цій системі, крім професійно зорієнтованого підходу до навчання, надзвичайно важливу роль повинна відігравати серйозна інформаційно-просвітницька робота, систематична й багатовекторна виховна праця (принцип «виховання через навчання»), що стане основою для формування національної свідомості майбутнього офіцера, командира, а отже, й для усвідомлення його власної національної ідентичності. Відповідно саме це дозволить кожному осмислено, аргументовано відповісти на архіважливе питання щодо своєї приналежності або «національно-культурної тожсамості» [1, с. 24].

Аналіз наукових досліджень і публікацій. Питання, пов'язані із формуванням національної ідентичності, духовним становленням і розвитком особистості загалом, були предметом дослідження багатьох українських науковців, зокрема П. Юркевича, М. Костомарова, В. Липинського, Д. Чижевського, чиї праці набули нового звучання у контексті сьогодення. Досліджувати окреслені проблеми продовжують О. Вишневський, Я. Грицак, В. Кремінь, С. Андрусів, С. Кримський, О. Пахльовська та ін. Учені вважають, що національна ідентичність передбачає самовизначеність особи в національному контексті, здатність усвідомлювати свою причетність 
до певної нації, до її основоположних модусів, зокрема мови, культури, релігії, філософії тощо. У наш час у суспільстві, обтяженому суспільно-політичними потрясіннями, сформульована проблема особливо актуальна для вищої школи, що готує фахівців для Збройних сил.

Мета статті - обгрунтувати зміст понять «національна свідомість», «національна ідентичність», «самоідентифікація» в сучасному молодіжному середовищі, проаналізувати значення їх формування у ВЗВО.

Виклад основного матеріалу. Відомий філософ С. Кримський стверджує, що в наш час, «коли філософія дедалі щільніше зрощується 3 людинознавством, соціальний інтелект епохи зацікавлений уже, перефразовуючи Ніцше, не стільки ниткою Аріадни i не маршрутом у лабіринті, скільки самою Аріадною. На перший план висувається персоноцентризм» [2, с. 9]. Звідси розуміємо, що проблема національної ідентичності, самоусвідомлення кожного в тій чи іншій національній спільноті фокусується в окремій людині, а від цього залежить і «ціннісно-смисловий універсум» усієї нашої держави [2, с. 9].

Через розв'язання проблеми національної ідентичності пройшли майже всі європейські держави, тому Україна не оригінальна у своєму прагненні до власної національної ідентифікації. Зважаючи на історичний досвід, за твердженням професора Карлового університету М. Хроха, сьогодення, як і сто років тому, знову висунуло перед Україною ті самі завдання: спільна історична пам'ять, міцність та інтенсивність мовних і культурних зв'язків i, зрештою, загальна рівність людей, організованих у громадянське суспільство [7, с. 124]. Безсумнівно, насамперед саме в середовищі молодого покоління повинні стояти усвідомлені питання про власне місце у світі, про приналежність самого себе до тієї чи іншої соціальної групи, національної спільноти: «Ким ми були, $є$ і ким хочемо бути?», «Задля чого готові жити й віддати життя у разі потреби?». I безперервність має бути основним модусом у пошуках відповіді на ці питання.

За останні більше ніж двадцять років розв'язання всіх трьох завдань - досягнення спільної історичної пам'яті, належної міцності мовних зв'язків, а також потужної розбудови громадянського суспільства не були реалізовані й вимагають першочергового вирішення, оскільки означена проблема в нашій країні втратила ознаки громадського дискурсу й набула форми гострого конфлікту.

Іспанський філософ Хосе Ортега-і-Гассет свого часу зазначав, що для нації важливіше мати не стільки спільне минуле, скільки спільне майбутнє, тобто перспективу розбудови спільного життя в соціальному довкіллі. Тому перед українською освітою постало завдання формування національної самосвідомості населення, що є вирішальним чинником впливу держави на цей процес. Відповідно до норм Закону України «Про вищу освіту» навчальні заклади, отримавши автономію, повинні впроваджувати й підтримувати політику ідентичності в освітянській галузі, а міністерства, що відповідають за освітню діяльність й уособлюють державу, зобов'язані їм сприяти. Передаючи права на самоврядування навчальним закладам, держава повинна вимагати від них не лише підготовки професіоналів, а й патріотів. У законі читаємо, що в процесі навчальної діяльності потрібно забезпечити виховання гармонійно розвинутої людини, а завданням вишу є «формувати особистості шляхом патріотичного, правового, екологічного виховання, утвердження в учасників освітнього процесу моральних цінностей, соціальної активності, громадянської позиції та відповідальності...» й «збереження та примноження моральних, культурних, наукових цінностей і досягнень суспільства» [4].

У 2015 році Президент України підписав Указ «Про Стратегію національно-патріотичного виховання дітей та молоді на 2016-2020 роки» [6]. Оскільки стратегія має на меті, зокрема, патріотичне виховання громадянина зі стійкою національною ідентичністю, то ії положення $\epsilon$ актуальними не лише для сфери виховання й навчання, а й для всіх державних органів, інституцій громадянського суспільства. Гармонійний розвиток студента як особистості та формування його національної самосвідомості $є$ основною метою Концепції сучасної освіти, тому перед викладачами сучасного закладу вищої освіти, а саме військових, стоїть важливе завдання - не тільки дати грунтовні знання, а й виховати покоління патріотів своєї держави, спадкоємців і продовжувачів національно-патріотичних традицій.

Сторонами педагогічної взаємодії $є$, безумовно, дві ланки - студент / курсант і викладач, при цьому обидві сторони однаково розуміють поняття «національна ідентичність» та «свідомість». Звісно, для курсантів і студентів у наш глобалізаційний час найбільш доступним і бажаним джерелом інформації $є$ Інтернет. «Вікіпедія» термін «національна ідентичність» трактує як «самовизначення особи в національному контексті, усвідомлення власної причетності до певної нації та ії системи цінностей: мови, релігії, етичних норм, культурної спадщини тощо» [3].

Досить часто два параметри - «етнічна ідентичність» і «національна ідентичність» - збігаються. Це залежить, очевидно, від національної свідомості, що $\epsilon$ «сукупністю соціальних, економічних, політичних, моральних, етичних, філософських, релігійних поглядів, норм поведінки, звичаїв і традицій, ціннісних орієнтацій та ідеалів, в яких виявляються особливості життєдіяльності націй та етносів» [3]. Звісно, дехто може скептично висловити сумніви щодо ступеня довіри до Вікіпедії, проте видатний український мовознавець Іван Ющук уважає, що таке вкрай важливе поняття для національної ідентичності, як «рідна мова» найбільш науково і повно сформульовано саме у Вікіпедії [8, с. 11-12].

Отже, загалом у вищій школі маємо справу зі сформованими особистостями, на світогляд яких уплинула сім'я, школа, оточення, засоби масової інформації, проте водночас молода людина, навчаючись у стінах вищого військового навчального закладу, сприймає й чимало інших засобів впливу. У процесі спілкування на рівні курсант-викладач, здобуваючи щоденний досвід пізнання нового, курсант інтенсивно розширює свої світоглядні межі і зазвичай у цих межах 3'являється певна розбіжність між комплексом «старих» і «нових» знань. Причини зрозумілі, оскільки у ВЗВО навчаються курсанти із різних регіонів України, 3 інформаційним простором, у якому ведеться справжнє протиборство націєтворчих та імперських ідей. Це певною мірою негативно впливає на молоду людину, яка вступила на навчання та змінила звичне середовище. При цьому питання щодо національної ідентичності та національної свідомості часто трактувалися як другорядні або й зовсім не розглядалися. 
У зв'язку з цим і виникає означена розбіжність, або так званий когнітивний дисонанс, що стає своєрідним бар'єром у взаємодії, проте лише на початку спілкування.

У ВЗВО, як загалом і в цивільних, навчається молодь із різних регіонів країни, зі своєю шкалою цінностей і рівнем самоусвідомлення. Зважаючи на це, цьогоріч ми вирішили провести опитування першокурсників, майбутніх фахівців морально-психологічного забезпечення сухопутних військ і запропонували їм пояснити, як вони розуміють поняття «національна ідентичність», «національна свідомість». Результати свідчать, що 75\% (78 осіб) розуміють поняття «національна свідомість» та «національна ідентичність», $20 \%$ (23 особи) розуміють, але не можуть чітко пояснити й 4,5\% (5 осіб) - ніколи над цим не задумувалися. Очевидно, це і $є$ підтвердженням виникнення когнітивного дисонансу. Додатково було поставлене завдання назвати чинники, що впливають на формування національної свідомості та усвідомлення ідентичності особистості й майбутнього захисника держави зокрема. 54\% опитаних першість віддали мові, близько $17 \%$ вважають, що важливішою є церква й віра, 15\% - на перше місце ставлять знання історії і 14\% переконані, що свідомість формують звичаї та традиції. Отже, як свідчать результати опитування, майбутні захисники держави так чи інакше розуміють основоположні поняття, важливі для формування їх національної свідомості.

Знаково, що у формуванні національної свідомості саме мові молодь віддає пріоритет. На думку відомого мовознавця I. Ющука, надзвичайно важливим чинником формування національної ідентичності особистості є мова [8, с. 11-12]. Зважаючи на це, важливо враховувати роль комунікативної функції мови та значення слова як потужної зброї інформаційної війни, що набула нечуваної сили і негативно впливає не лише на мирне населення. Отже, виняткову увагу у ВЗВО, де навчаються курсанти з різних регіонів України, багато з яких схильні вважати, що «мовне питання» стало причиною ескалації не лише суспільно-політичного, а й військового конфлікту в Україні, потрібно приділяти мовному середовищу як потужному вектору у формуванні національної ідентичності. Саме у ВЗВО формується національно-патріотичний дух, науковий інтелект нації, а отже, й сучасної військової еліти. Найуспішними в науковому, професійному вимірі стають ті, у кого високий рівень мовної компетентності, хто через мову усвідомив свою самодостатність, своє призначення та місію.

Видатний педагог XVIII ст., наш колега-попередник Феофан Прокопович стверджував, що «різні види зброї можуть мати владу над тілом людини, а от виняткову владу над іiі духом має слово, саме воно може укріпити або зламати його» [5]. I такою силою володіє красномовство як духовний меч, котрий здобувають у навчальних класах та аудиторіях.

Учасники неоголошеної війни Росії проти України свідчать, що бойовий дух вселяє й підтримує у своїх підлеглих той офіцер-командир, який уміє налагодити особистісні стосунки зі своїм підрозділом, той, хто вміє побачити в кожному 3 воїнів особистість, доброзичливо до них ставиться.

Командир будь-якої військової ланки має вміти обрати й підтримати для досягнення професійної мети найбільш адекватний у конкретній ситуації стиль спілкування, тобто бути не просто мовцем, а й володіти належною мовною та мовленнєвою культурою.
Означені компетенції майбутні офіцери здобувають під час навчання у своїй alma-mater - військовій академії, зокрема на заняттях із навчальної дисципліни «Українська мова за професійним спрямування». Саме їй серед інших гуманітарних предметів належить пріоритетна роль, адже вона сприяє засвоєнню та виявленню знань, а пізніше й доведенню цих знань до підлеглих уже у практичній сфері. Одним із розділів навчальної дисципліни є курс «Військова риторика», що своїм змістом охоплює усі вагомі аспекти загальної й прикладної риторики - науки про красномовство. І3 метою формування й розвитку практичних навичок, використовуючи досвід відомих промовців, розроблено різні за рівнем складності практичні вправи й завдання, що сприяють оволодінню методами риторичного аналізу текстів різних типів. Це дає змогу тим, хто навчається, сформувати уважне і критичне ставлення до свого мовлення та сучасної суспільної національно зорієнтованої мовної практики.

В означеному контексті науково-педагогічний персонал військових закладів вищої освіти як важлива складова педагогічної взаємодії не має права забувати про роль і силу слова як одного із чинників формування національно свідомої особистості офіцера, захисника своєї держави. Адже саме він є основою того мовного середовища, що формує «гуманітарну ауру» захисника державних і національних інтересів, захисника свого народу, з мовою, історією, релігією і культурою якого він себе ідентифікує.

Висновки. Отже, аналізуючи поняття «національна свідомість», «національна ідентичність», «самоідентифікація» в сучасному молодіжному середовищі, а також ураховуючи результати опитування курсантів ВЗВО, бачимо, що у формуванні національної свідомості першочергову роль відіграє мова, і саме мовному середовищу як потужному вектору у формуванні національної ідентичності потрібно приділяти виняткову увагу. Основою того мовного середовища, що формує гуманітарний світогляд захисника державних і національних інтересів $\epsilon$ науково-педагогічний персонал як одна із ланок педагогічної взаємодії.

Переконані, що комплекс гуманітарних дисциплін, визначений навчальним планом закладу, комплекс організаційно-виховних заходів і, найголовніше, морально-психологічне, духовне наповнення «гуманітарної аури», мовне середовище сприятимуть усуненню когнітивного дисонансу і потужній розбудові національної свідомості кожного курсанта / студента.

\section{СПИСОК ВИКОРИСТАНОӤ ЛІТЕРАТУРИ}

1. Андрусів С. Модус національної ідентичності: Львівський текст $30-x$ років XX ст. Тернопіль : Джура, 2000. 340 с.

2. Кримський С. Під сигнатурою Софії. Київ : Видавничий дім «Києво-Могилянська академія», 2008.367 c.

3. Національна ідентичність. Вікіпедія : вебсайт. URL : http://uk.wikipedia.org/wiki (дата звернення: 29.09.2020).

4. Про вищу освіту : Закон України. Відомості Верховної Ради (ВВР). Ст. 2004. 2014. C. 37-38. URL: https://zakon.rada.gov.ua/laws/show/1556-18\#Text (дата звернення: 29.09.2020).

5. Прокопович Ф. Про риторичне мистецтво. $\Phi i$ лософські твори. Київ, 1979. Т. 1. С. 118-149. 
6. Про Стратегію національно-патріотичного виховання дітей та молоді на 2016-2020 роки : Указ Президента України № 580/2015. URL: http://zakon5. rada.gov.ua/laws/show/580/2015\#n16 (дата звернення: 29.09. 2020).

7. Хрох М. От национальных движений к полностью сформировавшейся нации : процесс строительства наций в Европе. Нации и нациионализм. Москва : Праксис, 2002. С. 118-149.

8. Ющук І. Рідна мова й інтелект. Слово просвіти. 2012. № 43. С. 11-12.

Дата надходження до редакиіi: 15.11.2020 p. 